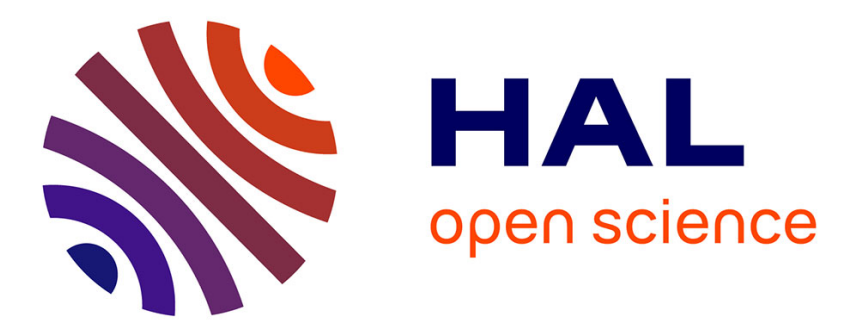

\title{
Bouchetispira ponderi n. sp. (Conoidea: Bouchetispiridae), a new deep-sea gastropod from temperate Australia
}

Anders Hallan, Francesco Criscione, Alexander E Fedosov, Nicolas Puillandre

\section{- To cite this version:}

Anders Hallan, Francesco Criscione, Alexander E Fedosov, Nicolas Puillandre. Bouchetispira ponderi n. sp. (Conoidea: Bouchetispiridae), a new deep-sea gastropod from temperate Australia. Molluscan Research, 2020, 40 (1), pp.86-92. 10.1080/13235818.2019.1681626 . hal-02559664

\section{HAL Id: hal-02559664 https://hal.science/hal-02559664}

Submitted on 30 Apr 2020

HAL is a multi-disciplinary open access archive for the deposit and dissemination of scientific research documents, whether they are published or not. The documents may come from teaching and research institutions in France or abroad, or from public or private research centers.
L'archive ouverte pluridisciplinaire HAL, est destinée au dépôt et à la diffusion de documents scientifiques de niveau recherche, publiés ou non, émanant des établissements d'enseignement et de recherche français ou étrangers, des laboratoires publics ou privés. 


\section{Molluscan Research}

\section{No longer a monotypic New Caledonian-endemic family: Bouchetispira ponderi $n$. sp. (Conoidea: Bouchetispiridae), a new deep-sea species from temperate Australia \\ --Manuscript Draft--}

Full Title:

Article Type:

Keywords:

Abstract:
No longer a monotypic New Caledonian-endemic family: Bouchetispira ponderi n. sp. (Conoidea: Bouchetispiridae), a new deep-sea species from temperate Australia

Article (taxonomic)

Neogastropoda; COI; molecular systematics; radula; shell morphology; convergence

This study reports the first record of the previously monotypic family Bouchetispiridae (Neogastropoda: Conoidea) outside of New Caledonia and provides the taxonomic description of Bouchetispira ponderi n. sp. from deep waters off the coast of New South Wales, Australia. Molecular analysis based on COI, 16S and 12S mitochondrial markers confirms its placement within the family, which is corroborated based on strong similarities of the shell and hypodermic radula to its sister taxon Bouchetispira vitrea. B. ponderi differs from the latter with regards to its shouldered, distinctly less convex whorls and a thicker, more opaque shell, as well as in details of the radula. Furthermore, the molecular results presented herein clearly support its recognition as a new species. B. ponderi bears remarkable similarities in shell morphology to Belomitra pacifica (Belomitridae), adding to the notion of rampant and complex shell homoplasy in the Neogastropoda. 
No longer a monotypic New Caledonian-endemic family: Bouchetispira ponderi n. sp.

(Conoidea: Bouchetispiridae), a new deep-sea species from temperate Australia

Anders Hallan ${ }^{A D}$, Francesco Criscione ${ }^{A}$ Alexander Fedosov ${ }^{B}$, Nicolas Puillandre ${ }^{C}$

A - Australian Museum, 1 William Street, Sydney NSW 2010, Australia

B - A.N. Severtsov Institute of Ecology and Evolution of Russian Academy of Sciences,

Leninski Prospect 33, Moscow 119071, Russia;

C - Institut Systématique Evolution Biodiversité (ISYEB), Muséum National d'Histoire

Naturelle, CNRS, Sorbonne Université, EPHE, Université des Antilles. 57 rue Cuvier, CP 26, 75005 Paris, France.

D - Corresponding author: anders.hallan@austmus.gov.au

Running Head: New deep-sea Bouchetispira from temperate Australia

Keywords: Neogastropoda, COI, molecular systematics, radula, shell morphology, convergence 


\begin{abstract}
This study reports the first record of the previously monotypic family Bouchetispiridae (Neogastropoda: Conoidea) outside of New Caledonia and provides the taxonomic description of Bouchetispira ponderi n. sp. from deep waters off the coast of New South Wales, Australia. Molecular analysis based on COI, 16S and 12S mitochondrial markers confirms its placement within the family, which is corroborated based on strong similarities of the shell and hypodermic radula to its sister taxon Bouchetispira vitrea. B. ponderi differs from the latter with regards to its shouldered, distinctly less convex whorls and a thicker, more opaque shell, as well as in details of the radula. Furthermore, the molecular results presented herein clearly support its recognition as a new species. B. ponderi bears remarkable similarities in shell morphology to Belomitra pacifica (Belomitridae), adding to the notion of rampant and complex shell homoplasy in the Neogastropoda.
\end{abstract}

\title{
Introduction
}

Intensive efforts to understand the evolutionary relationships of the Conoidea, the most diverse superfamily of the Mollusca, have in recent years resulted in significant advances towards achieving a high-resolution, stable classification of the group. Where, until recently, very few family-level taxa comprised the entire superfamily, numerous studies have since refined the classification framework to now encompass 18 families (Bouchet et al. 2011; Puillandre et al. 2011; Abdelkrim et al. 2018). While the taxonomic integrity of a few, most notably the Borsoniidae, appears fractious (Abdelkrim et al. 2018), the majority are welldefined molecular lineages now subject to ongoing taxonomical scrutiny in light of this rapid nomenclatural proliferation. One such family is the monotypic Bouchetispiridae, until recently only known from New Caledonia, and recognised as sister group to the conchologically very different Mitromorphidae (Kantor, Strong, et al. 2012). Recorded from relatively deep water ( $>600 \mathrm{~m}$ ), the family was delineated based on its unique combination of characters previously unseen in the Conoidea, including a multi-layered muscular bulb, punctate protoconch and distinct radular morphology.

Recent deep-sea expeditions in southern and eastern Australia aboard the research vessel Investigator have revealed considerable amounts of previously undiscovered conoidean lineages now subject to ongoing collaborative study between the Australian Museum, Sydney (AM), and Muséum National d'Histoire Naturelle, Paris (MNHN). Included in this material are two specimens retrieved from around $2600 \mathrm{~m}$ depth off the central coast of New South Wales, with a peculiar shell morphology suggesting non-conoidean affinities and thus of 
problematic attribution to a specific conoidean family. Herein, based on molecular and morphological analyses of this material, we describe a new species of Bouchetispira and as such, provide the first record of this enigmatic family from outside New Caledonia. Providing detailed accounts of the shell, anatomy and radula, we compare this new taxon to its sole family counterpart and discuss this new find in a broader phylogenetic context.

\section{Materials and Methods}

\section{Examined material}

Both specimens were collected in the Hunter Commonwealth Marine Reserve (Fig. 1) during the expedition 'Sampling the Abyss' (IN2017_V03), led by Museum Victoria and supported by CSIRO and NESP Marine Biodiversity Hub, and conducted onboard the Marine National Facility R/V Investigator. The studied material is deposited in the Malacology Collection of the Australian Museum, Sydney (AM).

\section{Molecular methods}

DNA was extracted from foot tissue of the specimens AM C. 519283 and C.571746 by use of a BIOLINE ISOLATE II Genomic DNA extraction kit for animal tissue, following the standard procedure of the manual. Fragments of two mitochondrial genes, cytochrome c oxidase subunit 1 (COI) and 12S rRNA (12S) were amplified by PCR using the primer pairs L1490/H2198 (Folmer et al. 1994) and 12S-I/12S-III (Simon et al. 1991) respectively. Reactions were performed with an annealing step of 30 s at $50^{\circ} \mathrm{C}$ for $\mathrm{COI}$ and at $57^{\circ} \mathrm{C}$ for $12 \mathrm{~S}$ with elongation times of 60s. Both strands of PCR fragments were purified with ExoSAP (Affymetrix) and cycle sequenced by use of the PCR primers. Chromatograms were manually corrected for misreads, if necessary, and forward and reverse strands were merged into one sequence file using CodonCode Aligner v. 3.6.1 (CodonCode Corporation, Dedham, MA). Sequences have been deposited in GenBank (AN: MK798109-11).

Phylogenetic trees were constructed using COI, 16S and 12S sequences from the set of taxa analysed in Kantor, Strong, et al. (2012) to which two COI and one 12S newly generated sequences were added. Sequences were manually (COI) or automatically (16S and $12 \mathrm{~S}$ ) aligned using MAFFT online (Rozewicki et al. 2017) by applying the automatic selection of the alignment strategy. Prior to the model-based phylogenetic analyses, the best-fit model of nucleotide substitution was identified for each gene partition (each gene separately, and each codon-position for the COI gene) following the Bayesian Information Criterion calculated 
with MrModeltest (Nylander 2002). The tests revealed the HKY model (Hasegawa et al. $1985)$ with gamma distribution and proportions of invariable sites $(\mathrm{HKY}+\Gamma+\mathrm{I})$ as the best-fit model of sequence evolution for COI and the General Time Reversible model (Tavaré 1986) with gamma distribution and proportions of invariable sites $(\mathrm{GTR}+\Gamma+\mathrm{I})$ for $16 \mathrm{~S}$ and $12 \mathrm{~S}$. Phylogenetic analyses were first performed on each gene separately to check for inconsistency between trees. As no supported incongruences were found, all genes were concatenated in a single dataset. Bayesian Inferences (BI) were performed using MrBayes 3 (Ronquist and Huelsenbeck 2003). The parameters of the substitution models were estimated separately for each partition. The analysis included 2 runs of $10^{7}$ generations, with 4 chains each and a sampling frequency of one tree each 1,000 generations. Other parameters were set by default. A consensus tree was then calculated after discarding the first $25 \%$ trees as burnin. Uncorrected pairwise genetic distances were calculated using MEGA6 (Tamura et al. 2013) under the option 'pair-wise deletion of gaps'.

\section{Morphological examinations}

Using digital callipers and with the aperture of specimens facing up, the following homologous structures were measured of the shell: total length (bottom of siphonal canal to tip of apex); maximum diameter of last whorl; height of aperture (bottom of siphonal canal to point where the outer aperture lip meets parietal wall); length of last whorl (bottom of siphonal canal to point of suture between penultimate and last whorls). When removed from ethanol, the animals were briefly rehydrated in distilled water. Using standard dissection tools, the venom apparatus was excised from one specimen. The radular sac was isolated and dissolved in diluted bleach and the radula mounted on a glass stub affixed to a carbon adhesive which was placed on a $12 \mathrm{~mm}$ diameter aluminium mount. The sample was imaged at Macquarie University, Sydney, using a Phenom XL Scanning Electron Microscope.

\section{Results}

\section{Molecular phylogenetics}

The phylogenetic tree (Fig. 2) confirmed the distinctiveness of $B$. ponderi n. sp. from $B$. vitrea, as suggested by the morphological characters (see below). The BI tree supported the inclusion of B. ponderi n. sp. in the Bouchetispiridae and in the genus Bouchetispira (Posterior Probability $=1$ ). The genetic distance between COI sequences of $B$. ponderi n.sp. and $B$. vitrea is $6 \%$. 


\title{
Systematics
}

\author{
Order Neogastropoda Wenz, 1938 \\ Superfamily Conoidea Fleming, 1822 \\ Family Bouchetispiridae Kantor, Strong \& Puillandre 2012 \\ Bouchetispira Kantor, Strong \& Puillandre 2012 \\ Bouchetispira ponderi n. sp.
}

Figs 3-5

\section{Material examined}

Holotype: Australia, New South Wales, Hunter Commonwealth Marine Reserve, $32^{\circ} 34.50^{\prime S}$, $153^{\circ} 09.72^{\prime}$ E, 2595 m, IN2017_V03 - Sampling the Abyss, 3 Jun. 2017, ethanol-preserved (AM C.571746).

Paratype: As for holotype, ethanol-preserved (AM C.519283).

ZooBank registration: urn: 1sid:zoobank.org:act:7F97962A-8369-4474-913EB4A3D23DC3AF

\section{Description}

Shell dimensions provided in Table 1. Shell (Fig. 3) of medium size, elongate-fusiform, thinwalled, semi-translucent, with high spire. Protoconch missing. Teleoconch of about six paleyellowish whorls, columella and base of last whorl distinctly paler. Whorls slender, early whorls with convex profile, later ones with moderately wide, well-defined, slightly concave subsutural ramp. Shoulder not pronounced on early whorls, rather distinct at penultimate and last whorl, at approximately adapical third of whorl. Axial sculpture of weak, rounded, orthocline ribs (about 18 on penultimate whorl, 32 on last whorl), becoming weak to obsolete toward base of last whorl, rib interspaces narrowing toward last adult whorl. Spiral sculpture of dense, equally interspaced cords (about 13 on penultimate whorl, 25+ on last whorl), producing weak nodules at intersections with axials, very weak on subsutural ramp. Microsculpture of growth lines. Last whorl evenly convex below subsutural ramp, weakly delimited from moderately long, straight, tapering siphonal canal. Aperture elongate, over a third of total shell length; outer lip thin, unsculptured; inner lip whitish, with distinct callus, basal half gently undulating. Anal sinus not pronounced. 
Cephalic tentacles (Fig. 4A) moderately long, very broad, massive, rather cylindrical, with transverse folds of epithelium; tip blunt. Eyes situated just above base on outer side of cephalic tentacles. Funnel moderately broad, subcylindrical; rhynchostome with muscular walls, circular. Osphradium large. Venom apparatus (Fig. 4B) occupying much of rhynchocoel. Proboscis large, broad, conical, walls folded. Muscular bulb of medium size, elongate, postero-ventral to large, long and convoluted venom gland. Radular sac large. Radula (Fig. 5 - based on paratype) of long, straight hypodermic teeth attaining $200 \mu \mathrm{m}$ in length. Dorsal blade approximately 1/10 length of tooth; ventral barb absent. Constriction at approximately mid-length point of tooth, producing understated hour-glass shape. Terminal pore ovate, lateral, approximately $1 / 10$ of tooth length. Base with no distinct lateral process, base texture fine; basal pore on ventral side posterior to flap-like structure at base of tooth. Ligament narrow.

\section{Distribution}

Only known from type locality (Fig. 1).

\section{Remarks}

As the protoconch has been eroded in all available material, comparison with the sister taxon based on these characters is not possible. However, the new species can readily be distinguished from $B$. vitrea based on its shouldered, distinctly less convex whorl profile and its comparatively thicker, less translucent shell. In terms of radular characters, it can be differentiated by a comparatively larger basal pore and a more pronounced lateral constriction of the near-central part of the tooth. Based on overall shell morphology, B. ponderi bears remarkable similarity to the non-conoidean Belomitra pacifica (Dall, 1908) (Buccinoidea: Belomitridae) (Kantor, Puillandre, et al. 2012 fig. 5c-e). However, the species can be differentiated by the comparatively more prominent spiral cords in B. pacifica, and the more nodulose appearance of the $B$. pacifica, where axials and spirals intersect. Furthermore, $B$. pacifica also differs in its radula, bearing three teeth in transversal row, with a tricuspidate rachidian.

A large number of polychaete chaetae were recovered from the intestine upon dissection, suggesting polychaetes constitute at least part of the diet of $B$. ponderi.

Etymology: For Winston Frank Ponder, eminent Australian malacologist, in recognition of his support to $\mathrm{FC}$ and $\mathrm{AH}$ during this project and throughout their scientific careers. His name 
and that of Philippe Bouchet, are joined in the first taxon described for the above-mentioned project, to mark the start of a productive collaboration between Australian and French malacology.

\section{Discussion}

B. ponderi is readily distinguished from $B$. vitrea by a typical combination of morphological features of the shell and radular anatomy. Shell characters, however, can be highly plastic and vary according to environmental factors. For example, the thicker (and hence more opaque) shell of $B$. ponderi could be a result of response to increased predation pressure, as reported for other marine gastropods (Brookes and Rochette 2007). Furthermore, B. ponderi is found at a considerably lower depth (at least $1000 \mathrm{~m}$ deeper) than its New Caledonian congeneric. Here, pressure is much higher and temperature lower, both factors known to drive an increase in the solubility of calcium carbonate (Burton 1998). It is not unlikely that the unpolished shell surface of $B$. ponder $i$ is a consequence of the comparatively greater erosion experienced.

The radular morphology, most notably the lateral terminal and basal pores (Fig. 5), is the same in B. ponderi as in the type species. This configuration is also seen in the sister group of Bouchetispiridae, Mitromorphidae (Kantor, Strong, et al. 2012). Another radular character shared by members of both families is a lateral constriction, in which the tooth narrows notably near the mid-length point (Fig. 5; fig. 6 in Bouchet et al. (2011); Fig. 5 in Kantor et al., (2012)). Functionally, the lateral placement of the basal pore means that the pore is farther removed from the ligament, which could reduce interference of the latter during venom delivery. Another possible function is that, while holding the hypodermic tooth in the proboscis sphincter, the lateral pore can potentially be sealed to keep venom from leaking back into the proboscis; as such, the tooth can potentially store small amounts of venom. Such a possible function, while entirely hypothetical, would possibly be strengthened by a constriction along the mid-length of the tooth to mitigate leakage through the terminal pore. Based on the above, establishing whether the phenotypic distinctiveness of the two Bouchetispira is genetically determined is problematic. Therefore, a purely morphologybased recognition of $B$. ponderi as a new distinct species would be inadequate. However, B. ponderi and B. vitrea are well-differentiated from each other by substantial genetic distance in COI, which is of similar magnitude to that measured for other conoidean species (Puillandre et al. 2009; N. Puillandre et al. 2010; Nicolas Puillandre et al. 2010; Fedosov and Puillandre 2012; Kantor et al. 2017). Combined with the morphological and 
anatomical evidence, we consider these results sufficient for the recognition of $B$. ponderi as a distinct species. This conclusion is in accordance with recent studies where integrative taxonomy has been applied to alpha-taxonomy questions of several conoidean groups. Members of the Conoidea not belonging to Conidae or Terebridae, namely the heterogeneous and extremely diverse assemblage previously assigned to Turridae, are notorious for their remarkable degree of shell convergence. Notable examples include Sibogasyrinx (Cochlespiridae) and Leucosyrinx (Pseudomelatomidae), whose highly similar shells almost entirely camouflage their separate evolutionary histories, or the case of Toxicochlespira (Mangeliidae) and Cochlespira (Cohclespiridae), to name only a few. Equally puzzling has been the family provenance of $B$. ponderi in the Bouchetispiridae. While certainly similar in some ways to the type species, it is superficially far more similar to Belomitra pacifica, not closely related to the Conoidea lineage.). Albeit shell convergence is certainly not unique to the Conoidea, the combination of complex sculptural elements and gross shell morphology replicated across evolutionary separate lineages is noteworthy.

Discussing the evolutionary history of the B. vitrea, Kantor et al. (2012) proposed two potential scenarios: i) it is the sole survivor of an ancient radiation, or ii) it originated in the complex and highly endemic seamount habitats surrounding New Caledonia. While not resolving these dual hypotheses, the findings herein do, to the small extent possible given the limited material available, support the former.

\section{Acknowledgments}

This work has been made possible through financial support from the Australian Government (ABRS grant RF217-57 to FC). The participation of AF was also supported by the Russian Science Foundation (grant 16-14-10118 to Yuri Kantor). Special thanks are due to Sue Lindsay and Chao Shen (Macquarie University, Sydney) for assisting with SEM work and Mandy Reid and Alison Miller (AM) for smoothly and promptly handling our requests. The authors wish to thank the CSIRO Marine National Facility (MNF) for its support in the form of sea time on RV Investigator, support personnel, scientific equipment and data management. All data and samples acquired on the voyage are made publicly available in accordance with MNF Policy. We also thank all the scientific staff and crew who participated in voyage IN2017_V03. Funding for the voyage was provided by the Marine Biodiversity Hub, supported through the Australian Government's National Environmental Science Program (NESP). 


\section{References}

Abdelkrim, J., Aznar-Cormano, L., Fedosov, A. E., Kantor, Y. I., Lozouet, P., Phuong, M. A., Zaharias, P. \& Puillandre, N. (2018) Exon-Capture-Based Phylogeny and Diversification of the Venomous Gastropods (Neogastropoda, Conoidea). Molecular Biology and Evolution 35, 2355-2374.

Bouchet, P., Kantor, Y. I., Sysoev, A. \& Puillandre, N. (2011) A new operational classification of the Conoidea (Gastropoda). Journal of Molluscan Studies 77, 273308.

Brookes, J. I. \& Rochette, R. (2007) Mechanism of a plastic phenotypic response: predatorinduced shell thickening in the intertidal gastropod Littorina obtusata. Journal of Evolutionary Biology 20, 1015-1027.

Burton, E. A. (1998) Carbonate carbonatescompensation depthcompensation depth. In: Geochemistry. Springer Netherlands, Dordrecht, pp. 73-73.

Fedosov, A. E. \& Puillandre, N. (2012) Phylogeny and taxonomy of the KermiaPseudodaphnella (Mollusca: Gastropoda: Raphitomidae) genus complex: a remarkable radiation via diversification of larval development. Systematics and Biodiversity 10, 447-477.

Folmer, O., Black, M., Hoeh, W., Lutz, R. \& Vrijenhoek, R. (1994) DNA primers for amplification of mitochondrial cytochrome c oxidase subunit I from diverse metazoan invertebrates. Molecular Marine Biology and Biotechnology 3, 294-299.

Hasegawa, M., Kishino, H. \& Yano, T. (1985) Dating of the human-ape splitting by a molecular clock of mitochondrial DNA. Journal of Molecular Evolution 22, 160-174.

Kantor, Y. I., Puillandre, N., Rivasseau, A. \& Bouchet, P. (2012) Neither a buccinid nor a turrid: A new family of deep-sea snails for Belomitra P. Fischer, 1883 (Mollusca, Neogastropoda), with a review of Recent Indo-Pacific species. Zootaxa 3496, 1-64.

Kantor, Y. I., Stahlschmidt, P., Aznar-Cormano, L., Bouchet, P. \& Puillandre, N. (2017) Too familiar to be questioned? Revisiting the Crassispira cerithina species complex (Gastropoda: Conoidea: Pseudomelatomidae). Journal of Molluscan Studies 83, 4355.

Kantor, Y. I., Strong, E. E. \& Puillandre, N. (2012) A new lineage of Conoidea (Gastropoda: Neogastropoda) revealed by morphological and molecular data. Journal of Molluscan Studies 78, 246-255. 
Nylander, J. A. A. (2002) MrModeltest v2.0b. In. Department of Systematic Zoology, Uppsala University, Uppsala.

Puillandre, N., Baylac, M., Boisselier, M. C., Cruaud, C. \& Samadi, S. (2009) An integrative approach to species delimitation in Benthomangelia (Mollusca: Conoidea). Biological Journal of the Linnean Society 96, 696-708.

Puillandre, N., Cruaud, C. \& Kantor, Y. I. (2010) Cryptic species in Gemmuloborsonia (Gastropoda: Conoidea). Journal of Molluscan Studies 76, 11-23.

Puillandre, N., Kantor, Y. I., Sysoev, A., Couloux, A., Meyer, C., Rawlings, T., Todd, J. A. \& Bouchet, P. (2011) The dragon tamed? A molecular phylogeny of the Conoidea (Gastropoda). Journal of Molluscan Studies 77, 259-272.

Puillandre, N., Sysoev, A. V., Olivera, B. M., Couloux, A. \& Bouchet, P. (2010) Loss of planktotrophy and speciation: geographical fragmentation in the deep-water gastropod genus Bathytoma (Gastropoda, Conoidea) in the western Pacific. Systematics and Biodiversity 8, 371-394.

Ronquist, F. \& Huelsenbeck, J. P. (2003) MrBayes 3: Bayesian phylogenetic inference under mixed models. Bioinformatics 19, 1572-1574.

Rozewicki, J., Yamada, K. D. \& Katoh, K. (2017) MAFFT online service: multiple sequence alignment, interactive sequence choice and visualization.

Simon, C., Franke, A. \& Martin, A. (1991) The polymerase chain reaction: DNA extraction and amplification. NATO ASI Series Series H Cell Biology 57, 329-355.

Tamura, K., Stecher, G., Peterson, D., Filipski, A. \& Kumar, S. (2013) MEGA6: Molecular Evolutionary Genetics Analysis version 6.0. Molecular Biology and Evolution 30, 2725-2729.

Tavaré, S. (1986) Some probabilistic and statistical problems in the analysis of DNA sequences. Lectures on Mathematics in the Life Sciences 17, 57-86. 


\section{Figure captions}

Figure 1. Distribution of Bouchetispira species in the South Pacific. A square indicates the record of B. vitrea Kantor et al., 2012 and a circle that of B. ponderi. Scale bar: $2000 \mathrm{Km}$.

Figure 2. Bayesian consensus phylogram based on analyses of the concatenated COI, 16S and $12 \mathrm{~S}$ sequences. Numbers above branches indicate posterior probabilities (\%). $\mathrm{Ht}-$ holotype, $\mathrm{Pt}$ - paratype.

Figure 3. Shells of Bouchetispira ponderi n. sp. A. Holotype (AM C.571746). Right: apertural view. Left: lateral view. B. Paratype (AM C.519283). Right: apertural view. Left: lateral view.

Scale bar: $10 \mathrm{~mm}$.

Figure 4. Bouchetispira ponderi n. sp., anatomical characters of holotype (AM C.571746). A. Left view of head, showing cephalic tentacles (ct), eye (e), funnel (f) and rhynchostome (r). B. Right view of venom apparatus (details of salivary gland[s] unknown), showing muscular bulb (mb), proboscis (p), radular sac (rs) and venom gland (vg).

Figure 5. Hypodermic teeth of Bouchetispira ponderi n. sp. Paratype (AM C.519283). A. Dorsal view with narrow ligament (lig) attached to base. B. Lateral view showing laterally situated terminal pore (tp), dorsal blade (db), and the ventrally situated basal pore (bp). C. Lateral view, opposing side from where terminal pore is located. Scale bar: $50 \mu \mathrm{m}$. 
Table 1. Shell dimensions ( $\mathrm{mm}$ ) for holotype and paratype of B. ponderi $\mathrm{n}$. sp.

\begin{tabular}{|l|l|l|}
\hline & Holotype (C.571746) & Paratype (AM C.519283) \\
\hline Shell total length & 32.7 & 25.4 \\
\hline Aperture length & 13.8 & 11.5 \\
\hline Maximum width & 10.6 & 8.1 \\
\hline Length of last whorl & 21.5 & 16.5 \\
\hline
\end{tabular}




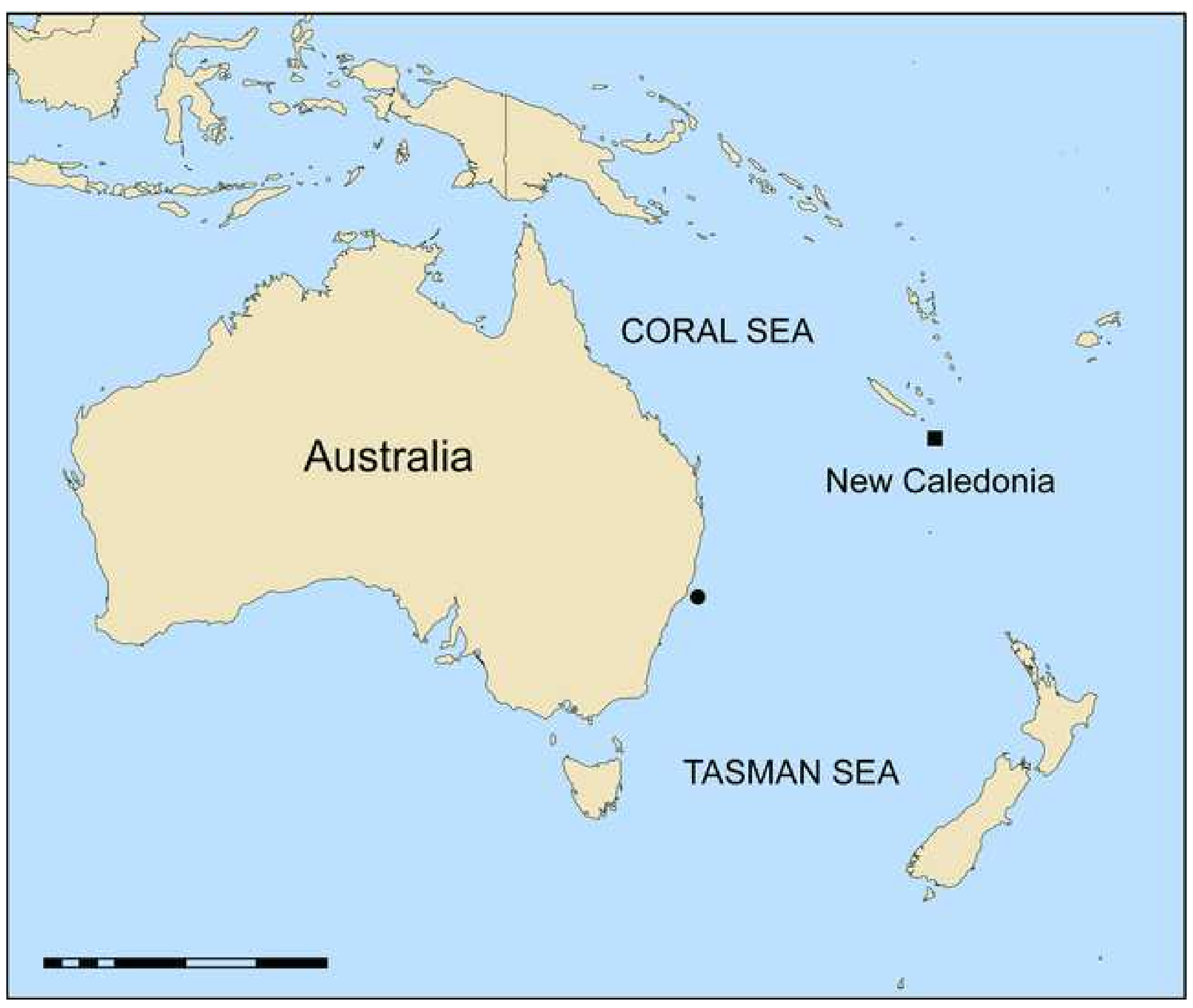


Laevistrombus guidai MNHN IM200911060

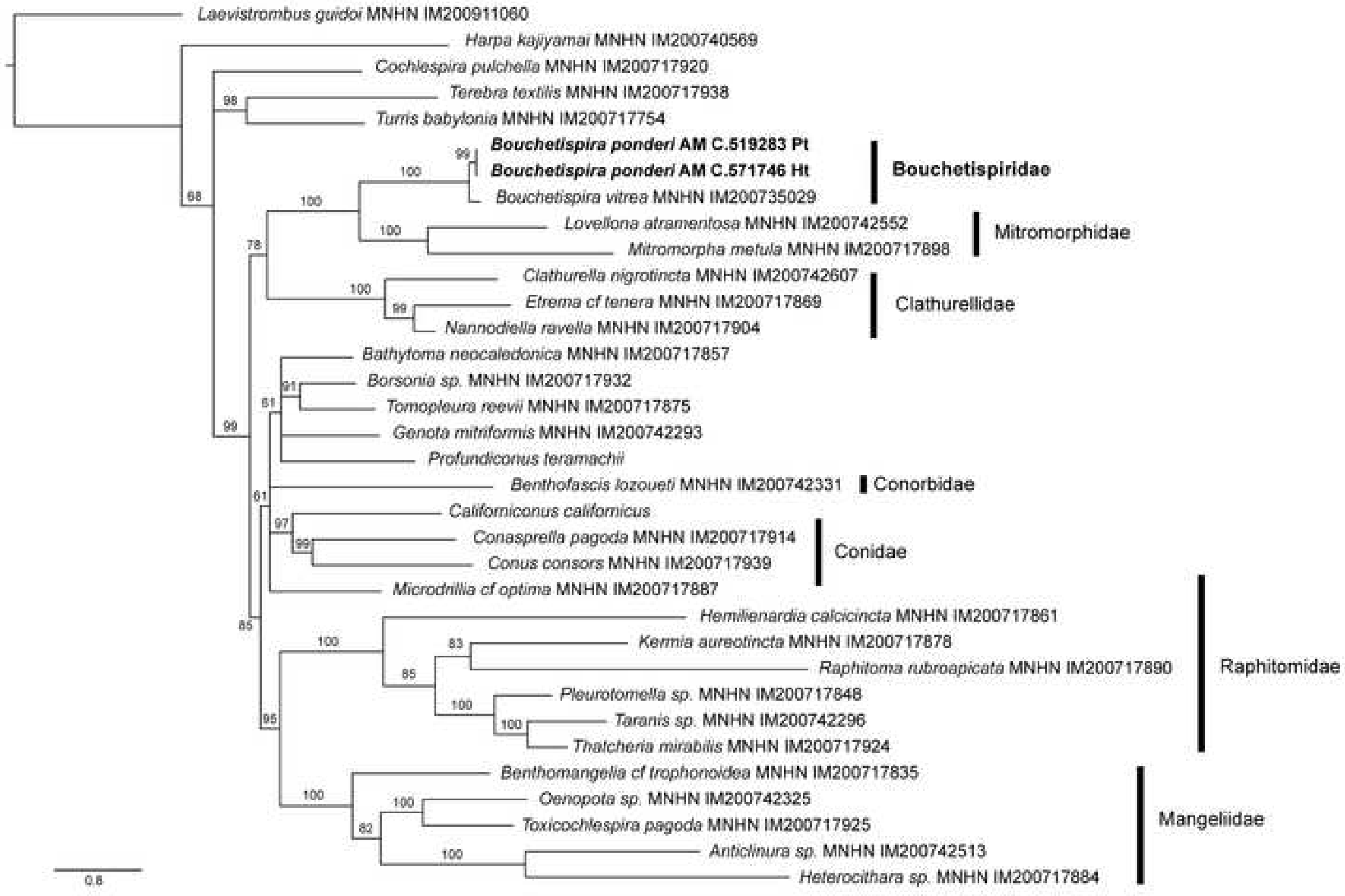

Hemilienardia caicicincta MNHN IM200717861 


$$
\text { BDA }
$$



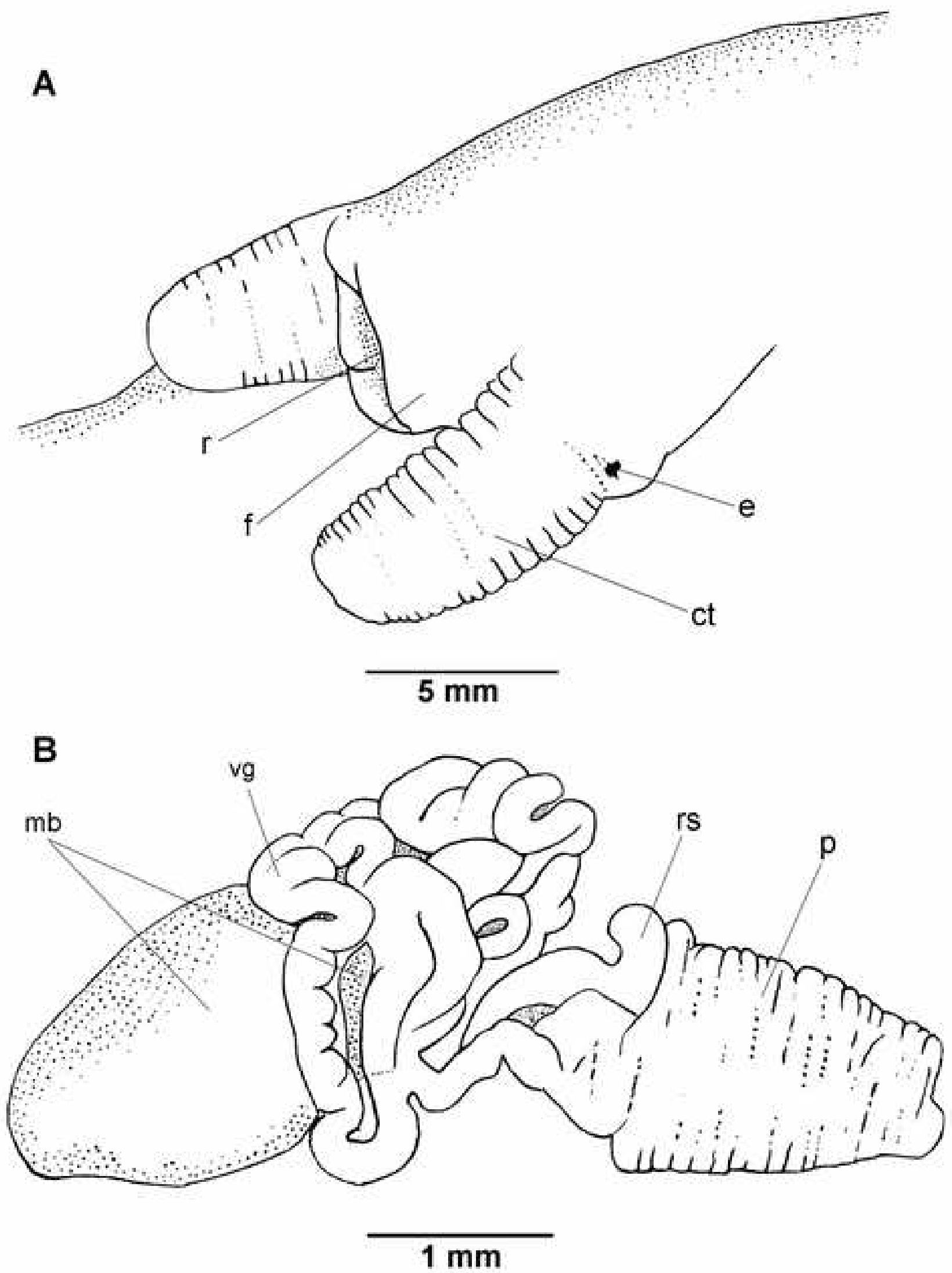
A

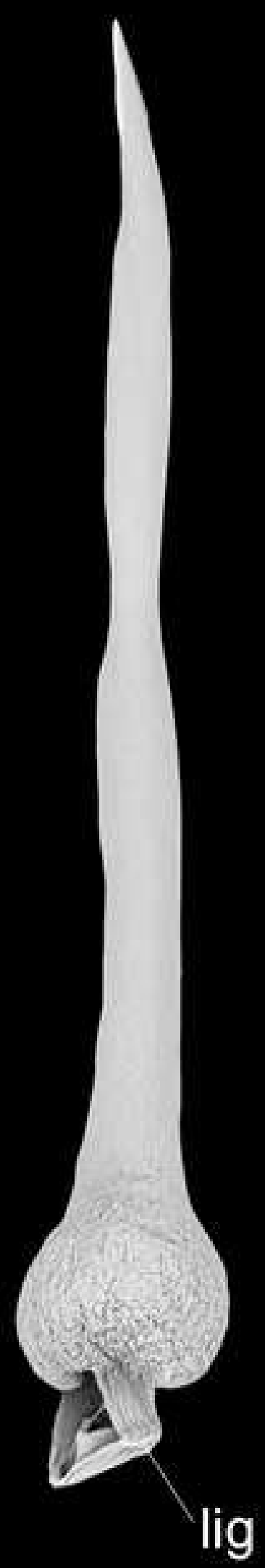

B

$\mathrm{db}$

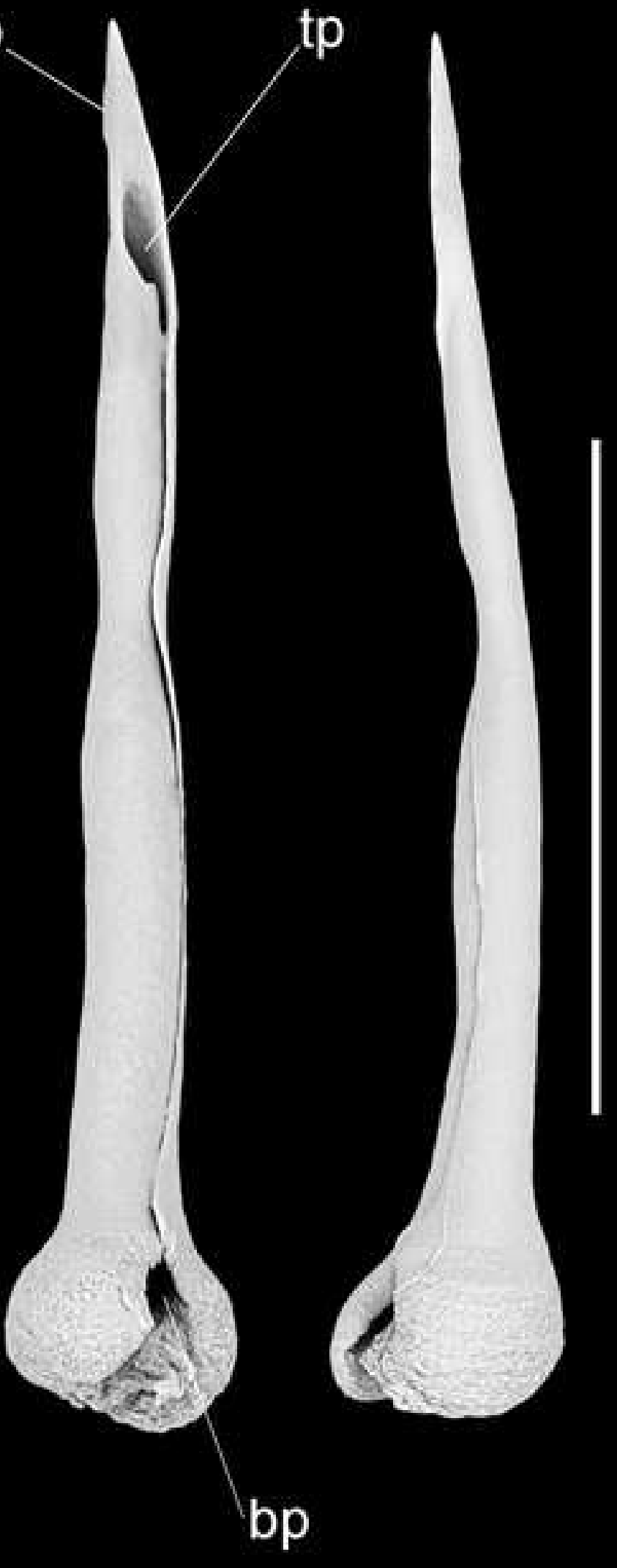

6 